\title{
Mycobacterium bohemicum sp. nov., a new slow-growing scotochromogenic mycobacterium
}

\author{
Udo Reischl, ${ }^{1}$ Stefan Emler, ${ }^{2}$ Zdenek Horak, ${ }^{3}$ Jarmila Kaustova, ${ }^{4}$ \\ Reiner M. Kroppenstedt, ${ }^{5}$ Norbert Lehn ${ }^{1}$ and Ludmila Naumann ${ }^{1}$
}

\begin{abstract}
Author for correspondence: Udo Reischl. Tel: +4994159609 50. Fax: +499419446402. e-mail: Udo.Reischl@klinik.uni-regensburg.de
\end{abstract}

\footnotetext{
1 Institute of Medical Microbiology and Hygiene, University of Regensburg, Franz-Josef-Strauß-Allee 11, D-93053 Regensburg, Germany

2 Central Laboratory of Bacteriology, University Hospital Geneva, 1211 Geneva, Switzerland

3 Masaryk Hospital, Usti N. Labem, Czech Republic

${ }^{4}$ National Reference Center for Mycobacterium kansasii, 72892 Ostrava, Czech Republic

${ }^{5}$ Deutsche Sammlung von Mikroorganismen und Zellkulturen $\mathrm{GmbH}$, D-38124 Braunschweig, Germany
}

\begin{abstract}
A new, slow-growing, scotochromogenic mycobacterium was isolated from sputum of a 53-year-old patient with Down's syndrome suffering from tuberculosis. Growth occurred at temperatures between 25 and $40{ }^{\circ} \mathrm{C}$ with an optimum at $37^{\circ} \mathrm{C}$. This strain had surprisingly few enzymic activities (only positive for $68^{\circ} \mathrm{C}$ heat-stable catalase and weakly positive for urease) and was sensitive to prothionamide, cycloserine, clarithromycin, gentamicin and amikacin but showed resistance to isoniazid, streptomycin, ethambutol, rifampin and ciprofloxacin. These characteristics assign this organism to a novel mycobacterial species characterized by a unique 16S rDNA nucleotide sequence. The name Mycobacterium bohemicum sp. nov. is proposed for this new, slow-growing, scotochromogenic mycobacterium. The type strain is DSM 44277'.
\end{abstract}

Keywords: Mycobacterium bohemicum sp. nov., 16S rDNA sequence, phylogenetic tree

\section{INTRODUCTION}

For decades the term mycobacteria was used as a synonym of Mycobacterium tuberculosis; this was true until other mycobacteria (atypical mycobacteria or mycobacteria other than Mycobacterium tuberculosis) were detected. The clinical significance of the latter is difficult to estimate because some are able to infect humans, but others have never been related to disease. Atypical mycobacteria are present in the human environment (Wolinsky, 1979) and may therefore be isolated from clinical specimens. For this reason, the isolation of atypical mycobacteria represents a clinical and taxonomic problem. The clinical significance has to be assessed (Corpe et al., 1963) and unambiguous microbial identification is needed. This, however, becomes more and more difficult with the increasing number of new mycobacterial species as some of these organisms may behave more or less alike when

The GenBank accession number for the sequence of the 16S rDNA of DSM $44277^{\top}$ is $U 84502$. conventional methods are used. In such cases $16 \mathrm{~S}$ rDNA analysis can provide definite identification (Springer et al., 1993). In strain DSM $44277^{\mathrm{T}}$ presented here, the lack of most of the enzymic activities characteristic of slow-growing mycobacteria rendered it easily identifiable by standard methods and analysis of the 16S rRNA gene yielded a characteristic unique sequence.

\section{METHODS}

Mycobacterial strain, cellular features, growth temperatures and biochemical tests. Strain DSM $44277^{\mathrm{T}}$ was isolated (Deutsches Institut für Normung, 1991; Deutsches Zentralkomitee zur Bekämpfung der Tuberkulose, 1991) from three consecutive sputum specimens. Growth was observed on Löwenstein-Jensen (LJ) medium and on 12 B medium (Kubica \& Wayne, 1984).

Besides microscopic and morphological investigations, the following features were studied: pigmentation, growth at 25 , $31,37,40$ and $45^{\circ} \mathrm{C}$, growth in the presence of $5 \% \mathrm{NaCl}$, niacin accumulation and nitrate reduction (Goodfellow \& 
Table 1. Selected criteria for the differentiation of slow-growing, pigmented mycobacteria

Data are from Goodfellow \& Wayne (1982), Kent \& Kubica (1985), Kubica \& Wayne (1984), Runyon et al. (1980) and Shinnick \& Good (1994). Symbols: -, less than 15\% of the isolates were positive; + , more than $85 \%$ of the isolates were positive; $\mathrm{v}, 16-85 \%$ of the isolates were positive; \pm , usually absent or a weak reaction was possible; $\mathrm{S}$, scotochromogenic; $\mathrm{P}$,

photochromogenic. Blank spaces indicate that the information is not currently available or that the property is unimportant.

Species

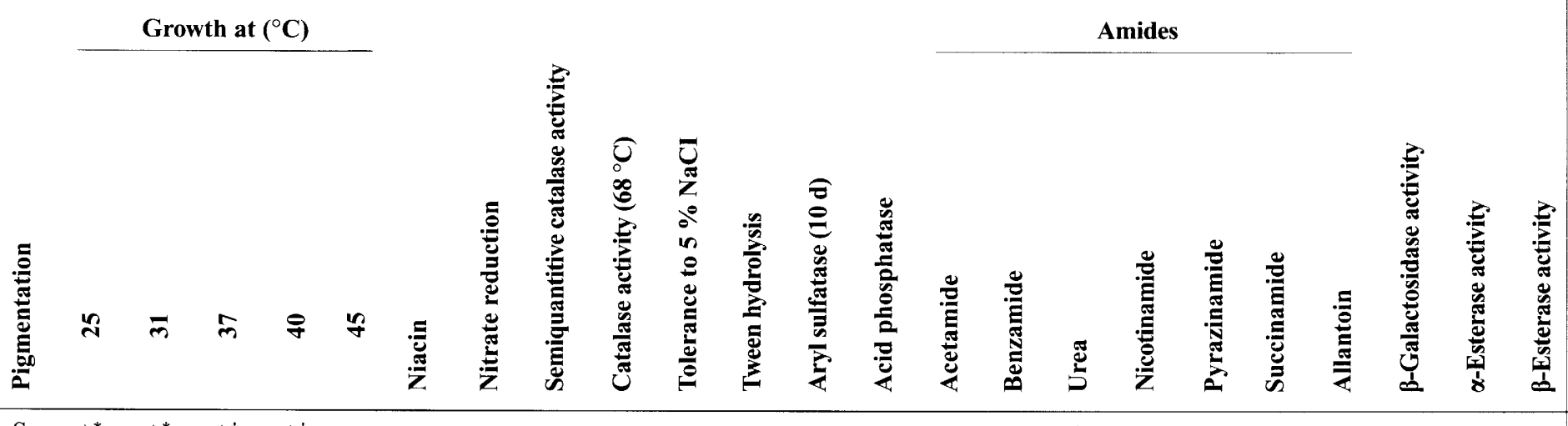

Mycobacterium bohemicum

Mycobacterium cookii

Mycobacterium farcinogenes

Mycobacterium gordonae

Mycobacterium hiberniae

Mycobacterium interjectum

Mycobacterium scrofulaceum

Mycobacterium szulgai

Mycobacterium xenopi

Mycobacterium asiaticum

Mycobacterium intermedium

Mycobacterium kansasii

Mycobacterium simiae

$\begin{array}{llllllll}\mathrm{S} & +^{*} & +^{*} & +\dagger & +\dagger & - & - & - \\ \mathrm{S} & + & & & - & - & & - \\ \mathrm{S} & & & & - & - & & + \\ \mathrm{S} & + & + & + & - & - & - & - \\ \mathrm{S} & + & & & & & & + \\ \mathrm{S} & - & & & - & - & & - \\ \mathrm{S} & + & + & + & \pm & - & - & - \\ \mathrm{S} & + & + & + & - & - & - & + \\ \mathrm{S} & - & - & + & + & + & - & - \\ \mathrm{P} & & + & + & & & - & - \\ \mathrm{P} & & & & & & - & - \\ \mathrm{P} & + & + & + & + & - & - & + \\ \mathrm{P} & + & + & + & \pm & - & + & -\end{array}$

*Visible growth was noted on LJ medium after 6 weeks incubation

$\dagger$ Visible growth was noted on LJ medium after 4 weeks incubation. 
Wayne, 1982; Kent \& Kubica, 1985; Kubica \& Wayne, 1984; Runyon et al., 1980; Shinnick \& Good, 1994). The biochemical properties examined are shown in Table 1 . Tests for drug susceptibility were performed on LJ medium and were interpreted by the modified proportion method (Deutsches Institut für Normung, 1991; Deutsches Zentralkomitee zur Bekämpfung der Tuberkulose, 1991). The properties of strain DSM $44277^{\mathrm{T}}$ and other slow-growing, pigmented mycobacteria are compared in Table 1 .

Culture conditions for fatty acid analysis. Strain DSM $44277^{\mathrm{T}}$ was cultivated on Middlebrook 7H10 agar (DSM medium No. 645; Deutsche Sammlung von Mikroorganismen und Zellkulturen, 1993) at $37^{\circ} \mathrm{C}$ for 1 week. To obtain sufficient cell material for analysis of chemical markers, the strain was grown in GPHF liquid medium (DSM medium 553; Deutsche Sammlung von Mikroorganismen und Zellkulturen, 1993).

Analyses of cell wall amino acids and sugars. Amino acids and sugars of whole-cell hydrolysates were analysed by TLC as described by Stanek \& Roberts (1974).

Extraction and analysis of isoprenoid quinones. Isoprenoid quinones were extracted and purified by the small-scale integrated procedure described by Minnikin et al. (1984). Once menaquinone was isolated and lyophilized, the preparation was dissolved in $200 \mu \mathrm{l}$ 2-propanol. Portions $(1-10 \mu \mathrm{l})$ were separated by HPLC without further purification using an RP-18 column $(250 \times 4 \mathrm{~mm})$ filled with Lichrospher 100 (particle size, $5 \mathrm{~mm}$ ). The column temperature was kept at $40^{\circ} \mathrm{C}$. Acetonitrile/2-propanol $(65: 35$, $\mathrm{v} / \mathrm{v}$ ) was used as mobile phase. The flow rate was $1 \mathrm{ml} \mathrm{\textrm {min } ^ { - 1 }}$ (Kroppenstedt, 1985; Kroppenstedt et al., 1981).

Extraction and analysis of fatty acids. Fatty acid methyl esters were obtained from $40 \mathrm{mg}$ (wet wt) of cells by saponification, methylation and extraction using minor modifications (Kuykendall et al., 1988) of the method of Miller (1982). The fatty acid methyl ester mixtures were analysed by using a model 5898A Microbial Identification System (Microbial ID). Peaks were automatically integrated and fatty acid names and percentages were determined by the Microbial Identification System standard software (Microbial ID). GC parameters were as follows: the carrier gas was ultrahigh purity hydrogen; column head pressure, 60 $\mathrm{kPa}$; injection volume, $2 \mathrm{ml}$; column split ratio, 100:1; septum purge, $5 \mathrm{ml} \mathrm{min}{ }^{-1}$; column temperature increased from 170 to $270^{\circ} \mathrm{C}$ at a rate of $5^{\circ} \mathrm{C} \mathrm{min}{ }^{-1}$; injection port temperature, $250{ }^{\circ} \mathrm{C}$; detector temperature, $300^{\circ} \mathrm{C}$.

Extraction and analysis of mycolic acids. Freeze-dried bacteria $\left(50 \mathrm{mg}\right.$ ) were degraded by treatment at $75^{\circ} \mathrm{C}$ with $3 \mathrm{ml}$ of a methanol/toluene/sulphuric acid mixture $(30: 15: 1$, by vol.) for $16 \mathrm{~h}$ (Minnikin et al., 1980). Long-chain components were extracted with hexane and traces of acid were removed by passage through a short column of ammonium hydrogen carbonate. The hexane extracts were examined by TLC and two-dimensional chromatography as described previously (Schröder et al., 1997).

Determination of the DNA G + C content. DNA was isolated by using procedures described by Visuvanathan et al. (1989). Approximately $20 \mu \mathrm{g}$ DNA was hydrolysed and dephosphorlylated as described by Mesbah et al. (1989). Nucleosides were separated by reversed-phase HPLC as described previously (Schröder et al., 1997) using the solvent system of Tamaoka \& Komagata (1984). The retention times of the nucleosides were determined with synthetic compounds.
Non-methylated $\lambda$ phage DNA with a $\mathrm{G}+\mathrm{C}$ content of $49.858 \mathrm{~mol} \%$ (Sanger et al., 1982) was used as a calibration reference. The $\mathrm{G}+\mathrm{C}$ contents were calculated automatically with a Shimadzu integrator.

PCR-based amplification of 165 rDNA. A single colony of the mycobacterial strain was collected from LJ medium and chromosomal DNA was extracted as previously described (Reischl et al., 1994). A $1 \mu \mathrm{g}$ portion of bacterial DNA was subjected to PCR with each of the following primer pairs: M285 and M264 (Kirschner et al., 1993) to obtain a $1030 \mathrm{bp}$ amplification product of the $16 \mathrm{~S}$ rDNA $5^{\prime}$ end; R247 $\left(5^{\prime}\right.$ GTAGTCCACGCCGTAAACGG 3') and M261 (Kirschner et al., 1993) to obtain an approximately $760 \mathrm{bp}$ amplification product of the $16 \mathrm{~S}$ rDNA $3^{\prime}$ end. Broad-range eubacterial primers M285 and M261 were combined with genus-specific primers M264 and R247 to produce a $246 \mathrm{bp}$ overlap between the two amplicons. Standard amplification mixtures were incubated at $95^{\circ} \mathrm{C}$ for $2 \mathrm{~min}, 68^{\circ} \mathrm{C}$ for $1 \mathrm{~min}$, $95^{\circ} \mathrm{C}$ for $1 \mathrm{~min}, 68^{\circ} \mathrm{C}$ for $1 \mathrm{~min}$ and $95^{\circ} \mathrm{C}$ for $1 \mathrm{~min}$, followed by 35 cycles of the following temperature profile: $95^{\circ} \mathrm{C}$ for $40 \mathrm{~s}, 55^{\circ} \mathrm{C}$ for $40 \mathrm{~s}$ and $72^{\circ} \mathrm{C}$ for $1.5 \mathrm{~min}$. The PCR mixtures were extracted with phenol and subjected to agarose gel electrophoresis. Extraction and purification of the amplicons were performed with a QiaEx-II purification kit (Qiagen).

DNA sequencing. Cycle sequencing reactions of the $16 \mathrm{~S}$ rDNA amplicons were carried out as described in the PRISM Ready Reaction Dye Deoxy Terminator Cycle Sequencing Kit protocol (Applied Biosystems). Optimal results were obtained with the following forward and reverse sequencing primers: M285 (Kirschner et al., 1993) and new primer R928 (5' CCTTTGAGTTTTAGCCTTGC 3') for the 1030 bp amplicon; new primer R249 (5' GGATCCGTGCCGTAGCTAACGC $3^{\prime}$ ) and M261 (Kirschner et al., 1993) for the $760 \mathrm{bp}$ amplicon. Both strands of the specific amplicons originating from different amplification reactions were sequenced in duplicate to rule out the possibility of Taq DNA polymerase-induced errors. The fluorescence-labelled reaction products were analysed with a model $373 \mathrm{~A}$ automated DNA sequencer (Applied Biosystems). The interpretation of the results was accomplished with the SeqEd 1.03 software package (Applied Biosystems).

Sequence and phylogenetic analysis. The sequence of the new strain was aligned with 30 16S rDNA reference sequences from closely related mycobacterial species by using Genetic Data Environment software version 2.2 (Larsen et al., 1993). No gaps were removed, while probable sequencing errors within the reference sequences were not weighted. A phylogenetic tree was constructed by using the neighbour-joining method (Saitou \& Nei, 1987), applied to distances corrected for multiple hits and for unequal transition and transversion rates according to Kimura's two-parameter model (Kimura, 1980), thus omitting parts of uncertain alignment at both ends of the gene. Tree positions were confirmed by parsimony analysis; bootstrapping was not performed due to the high degree of similarity of mycobacterial $16 \mathrm{~S}$ rDNA.

\section{RESULTS}

\section{Microscopy and culture}

Strain DSM $44277^{\mathrm{T}}$ showed acid-fastness like other slow-growing mycobacteria (Goodfellow \& Wayne, 1982; Kubica \& Wayne, 1984; Runyon et al., 1980). 
Table 2. Fatty acids of Mycobacterium bohemicum

\begin{tabular}{|lr|}
\hline Fatty acid & Area $(\boldsymbol{\%})$ \\
\hline $14: 0$ & $2 \cdot 55$ \\
$15: 0$ & $0 \cdot 53$ \\
$16: 1$ cis 9 & $1 \cdot 60$ \\
$16: 1$ cis 10 & $6 \cdot 13$ \\
$16: 0$ & $26 \cdot 93$ \\
$16: 1$ cis 7 & $2 \cdot 15$ \\
$17: 0$ & $0 \cdot 52$ \\
$18: 1$ cis 9 & $24 \cdot 42$ \\
$18: 0$ 10-methyl & $7 \cdot 48$ \\
$18: 2$ & $0 \cdot 39$ \\
$20: 0$ & $0 \cdot 67$ \\
$18: 0$ alcohol & $3 \cdot 46$ \\
$20: 0$ alcohol & $20 \cdot 34$ \\
\hline
\end{tabular}

The strain was scotochromogenic and grew at $25-40^{\circ} \mathrm{C}$ within 4-6 weeks after inoculation. At $37^{\circ} \mathrm{C}$, the colonies were about $1-2 \mathrm{~mm}$ in diameter. Temperatures between 37 and $40^{\circ} \mathrm{C}$ seemed to favour growth.

The strain did not grow on $\mathrm{NaCl}$. In general, enzymic activity was remarkably low; no accumulation of niacin, no reduction of nitrate, no hydrolysis of Tween 80 and no arylsulfatase and acid phosphatase activities were observed. In contrast, catalase activity at $37^{\circ} \mathrm{C}$ (43 $\mathrm{mm}$ ) was detected and was not inactivated by heating to $68^{\circ} \mathrm{C}$. No benzamidase, acetamidase, nicotinamidase, pyrazinamidase, succinamidase and allantoinamidase activities were observed. The activities of $\beta$-esterase, $\alpha$-esterase and $\beta$-galactosidase were negative while urease activity was weak.

The strain was susceptibile to cycloserine $\left(16 \mathrm{mg} \mathrm{l}^{-1}\right)$, prothionamide $\left(32 \mathrm{mg} \mathrm{l}^{-1}\right)$, clarithromycin $\left(2 \mathrm{mg} \mathrm{l}^{-1}\right)$, gentamicin $\left(2 \mathrm{mg} \mathrm{l}^{-1}\right)$ and amikacin $\left(2 \mathrm{mg} \mathrm{l}^{-1}\right)$, but resistant to isoniazid $\left(1 \mathrm{mg} \mathrm{l}^{-1}\right)$, rifampin $\left(32 \mathrm{mg} \mathrm{l}^{-1}\right)$, streptomycin $\left(8 \mathrm{mg} \mathrm{l}^{-1}\right)$, ethambutol $\left(2 \mathrm{mg} \mathrm{l}^{-1}\right)$ and ciprofloxacin $\left(4 \mathrm{mg}^{-1}\right)$.

\section{Chemotaxonomic analyses}

The cell walls of strain DSM $44277^{\mathrm{T}}$ contained arabinose and galactose as major cell wall sugars; meso-diaminopimelic acid was the only diamino acid. MK-9 $\left(\mathbf{H}_{2}\right)$ was the predominant menaquinone and small amounts of $\mathrm{MK}-8\left(\mathrm{H}_{2}\right)$ and $\mathrm{MK}-10\left(\mathrm{H}_{2}\right)$ were also detected. Analysis of the fatty acids from whole-cell
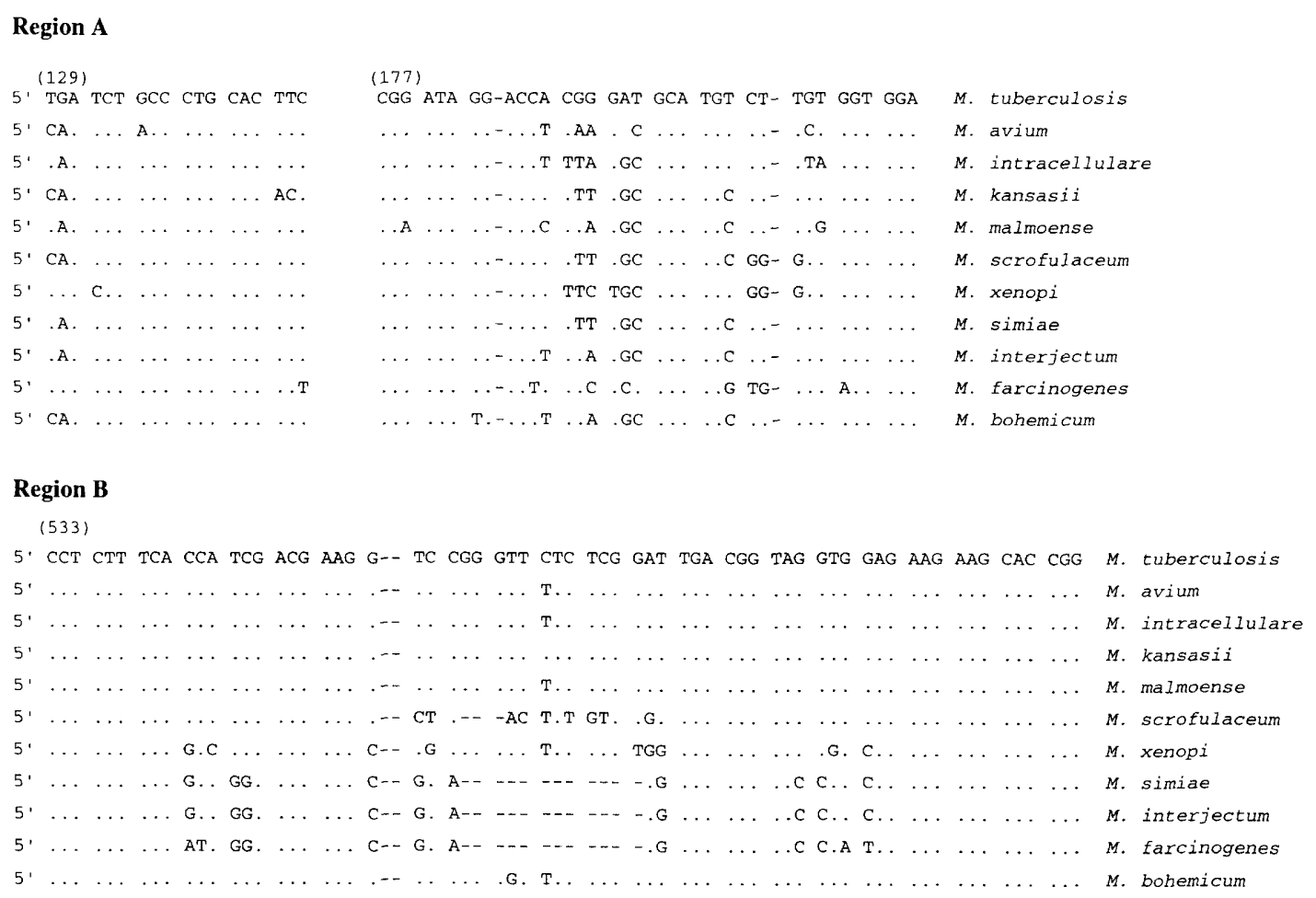

Fig. 1. Comparison of $16 \mathrm{~S}$ rDNA signature sequences (hypervariable regions $A$ and $B$; Kirschner et al., 1993) of selected species of the genus Mycobacterium including Mycobacterium bohemicum. Only nucleotides different from Mycobacterium tuberculosis are shown; dashes indicate deletions. The corresponding positions of the $E$. coli 165 rRNA gene are shown in parentheses for reference. The GenBank accession numbers for sequences are as follows: Mycobacterium tuberculosis, X52917; Mycobacterium avium, X52918; Mycobacterium intracellulare, X52927; Mycobacterium kansasii, X15916; Mycobacterium malmoense, X52930; Mycobacterium scrofulaceum, X52924; Mycobacterium xenopi, X52929; Mycobacterium simiae, X52931; Mycobacterium interjectum, X70961; Mycobacterium farcinogenes, X55592; Mycobacterium bohemicum, U84502. 
extracts revealed a pattern of straight-chain, saturated and unsaturated fatty acids along with significant amounts of tuberculostearic acid (10-methyloctadecanoic acid). Two alcohols, octadecanol and eicosanol were also present (Table 2). Strain DSM $44277^{\mathrm{T}}$ could not be precisely identified on the basis of its fatty acid pattern by using the MIDI mycobacterial database. However, the fatty acid pattern resembled a species of the Mycobacterium avium-intracellularescrofulaceum (MAIS) complex.

One-dimensional TLC of whole-organism acid methanolysates of strain DSM $44277^{\mathrm{T}}$ indicated that this organism synthesizes mycolic acids that include $\alpha$ mycolates and wax esters. Two-dimensional TLC resulted in a more precise separation of the components, especially of the $\alpha$-mycolmethoxyketo-wax esters and the ketomycolates, but only $\alpha$-mycolates and alcohols could be detected.

\section{$\mathbf{G}+\mathbf{C}$ content}

The $\mathrm{G}+\mathrm{C}$ content of strain DSM $44277^{\mathrm{T}}$ was 63.5 $\mathrm{mol} \%$.

\section{$16 S$ rRNA sequence analysis}

An almost complete nucleotide sequence of the gene encoding the small 16S rDNA subunit was determined. When compared to all publicly available mycobacterial 16S rDNA sequences in the GenBank sequence database, the sequence of strain DSM $44277^{\mathrm{T}}$ was found to be unique. Detailed examination of the $16 \mathrm{~S}$ rDNA sequence demonstrated complete homology in genus-specific regions, but revealed a number of differences in species-specific regions (Fig. 1). Thus, the sequence showed the characteristics of a slowgrowing mycobacterium with a long stretch in helix 18 (Springer et al., 1996). With regard to the variable region in helix 10 , the sequence clustered with the Mycobacterium avium-intracellulare complex and other slow-growers such as Mycobacterium szulgai and Mycobacierium kansasii. However, significant differences within this region allow easy discrimination of the novel species.

\section{Phylogenetic analysis}

Comparing the novel $16 \mathrm{~S}$ rDNA sequence to related 16S rDNA sequences from well established mycobacterial taxa, the phylogenetic position of the novel species could be determined (Kirschner et al., 1993; Rogall et al., 1990). A phylogenetic tree inferred from the results of the sequence comparisons is shown in Fig. 2. Some landmarks on this tree have been shown in a previously published study on mycobacterial phylogeny (Rogall et al., 1990). When calculating the homology score between all similar mycobacterial $16 \mathrm{~S}$ rDNA sequences, Mycobacterium kansasii ranked at the top (Fig. 2).

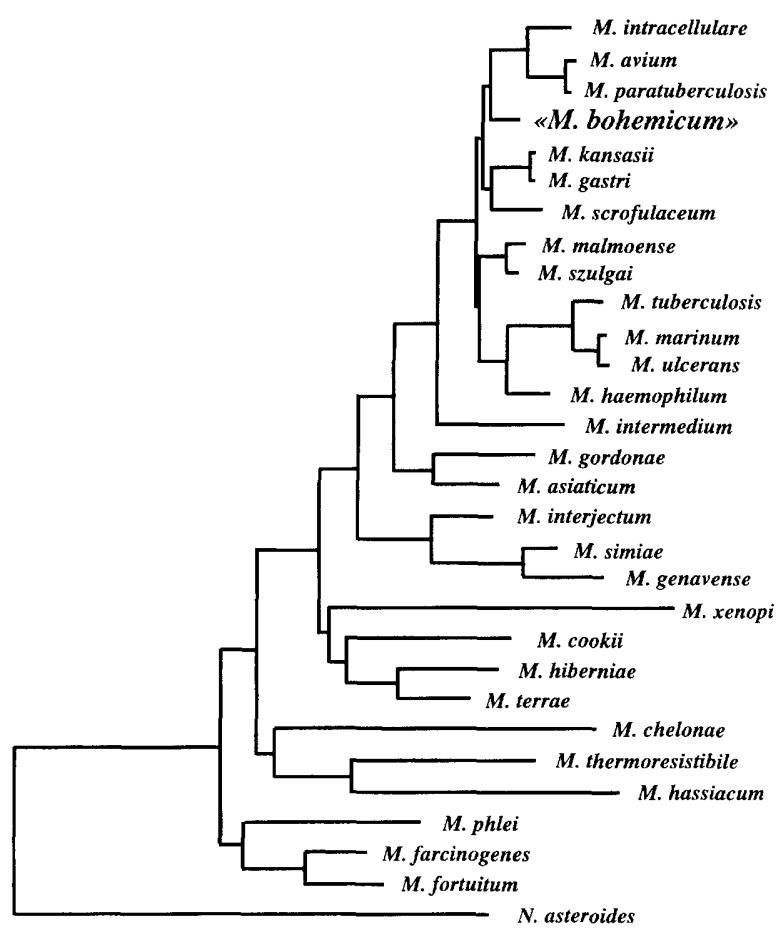

Fig. 2. Phylogenetic tree indicating the relationship of Mycobacterium bohemicum to selected mycobacterial species. The tree was inferred using the neighbour-joining method applied to distances corrected for multiple hits and for unequal transition and transversion rates by the Kimura's two parameter model. The tree was rooted by using Nocardia asteroides as an outgroup.

\section{DISCUSSION}

When detecting acid-fast bacilli in human specimens, it is of clinical and epidemiological importance to determine whether they belong to the highly pathogenic Mycobacterium tuberculosis complex. In the case of atypical mycobacteria, this finding often raises the question of real infection or colonization which often depends on the host's immune status; an answer to this question is needed since some atypical mycobacteria may be of clinical importance. In that situation, an unambiguous identification of the isolate may be neccessary. Strain DSM $44277^{\mathrm{T}}$ was isolated from consecutive sputum specimens from a 53-year-old patient with Down's syndrome who suffered from tuberculosis. The identification of an atypical mycobacterium isolated from a patient with known infection with Mycobacterium tuberculosis is crucial as it may have impact on treatment considerations.

Mycobacterium bohemicum is not readily distinguishable from other mycobacteria by conventional biochemical tests, as shown in Table 1, and is characterized by remarkably low enzymic activity. Within the extended panel of enzyme reactions tested, only heatstable catalase and weak urease activities were recorded, while tests for thermolabile catalase were negative, thus allowing the discrimination of $\mathrm{Myco}$ - 
bacterium bohemicum from other slow-growing scotochromogenic or photochromogenic mycobacteria.

Within the group of slow-growing mycobacteria, only Mycobacterium haemophilum has, as yet, a similar 'poor' spectrum of biochemical activities; since it is non-photochromogenic, it can be easily distinguished from Mycobacterium bohemicum visually. Among the rapid growers, the recently reported Mycobacterium hassiacum (Schröder et al., 1997) also shows a similar spectrum of biochemical activities; however, its thermophilic properties (rapid growth even at $65^{\circ} \mathrm{C}$ ) render it clearly different from the strain presented here.

With regard to HPLC analysis, the strain shows typical features which are characteristic for all species of the genus Mycobacterium. These include meso-diaminopimelic acid and arabinose plus galactose in whole-cell hydrolysates, quinone MK $-9\left(\mathrm{H}_{2}\right)$, a fatty acid pattern composed of unbranched saturated and unsaturated fatty acids plus tuberculostearic acid and mycolic acids having a chain length of about 90 carbon atoms. The occurrence of two alcohols, 18:0 and 20:0, in the fatty acid pattern (free of wax esters) places the strain into a cluster of species which also includes Mycobacterium avium, Mycobacterium intracellulare, Mycobacterium scrofulaceum, Mycobacterium terrae and Mycobacterium phlei.

Sequence analysis of the $16 \mathrm{~S}$ rRNA gene is a reliable method for mycobacterial identification and has proven its potential in the detection of new species (Böddinghaus et al., 1990; Kirschner et al., 1993; Schröder et al., 1997; Springer et al., 1993, 1996). Furthermore, dysgonic species such as Mycobacterium genavense could be misidentified without sequence analysis (Haas et al., 1993). However, some other species are easily distinguished by conventional procedures but cannot be differentiated at the $16 \mathrm{~S}$ rDNA level: Mycobacterium tuberculosis and Mycobacterium bovis, and Mycobacterium kansasii and Mycobacterium gastri share the same $16 \mathrm{~S}$ rDNA sequence while species such as Mycobacterium malmoense and Mycobacterium szulgai show a very high $16 \mathrm{~S}$ rDNA sequence similarity of $99.9 \%$ (Rogall et al., 1990).

Primers targeting the genus-specific regions of the $16 \mathrm{~S}$ rDNA can be used to amplify the entire 16S rRNA gene of about $1500 \mathrm{bp}$ of any mycobacterium (Böddinghaus et al., 1990, Springer et al., 1996). Overall 16S rDNA homology in mycobacteria exceeds $90 \%$. Therefore, sequencing errors might easily lead to the description of 'novel species'. However, the finding of a novel signature sequence in the so-called variable regions for mycobacteria (position 129-266, Escherichia coli numbering; Kirschner et al., 1993) together with distinct phenotypical properties leads to the assumption that a new species has been detected. Characteristic mismatches of the Mycobacterium bohemicum 16S rDNA signature sequence to the sequences of similar species, such as Mycobacterium kansasii, Mycobacterium avium, Mycobacterium intracellulare or Mycobacterium szulgai, may therefore provide a target for specific DNA probes or other nucleic-acid-based diagnostic procedures for its specific recognition (Fig. 1).

\section{Description of Mycobacterium bohemicum sp. nov.}

Mycobacterium bohemicum (bo.he'mi.cum. M.L. adj. bohemicum referring to the Czech Republic where the organism was first isolated).

Rod-shaped cells show acid-alcohol fastness. Colonies grown on LJ medium are scotochromogenic and $1-2 \mathrm{~mm}$ in diameter. Grows at temperatures between 25 and $40{ }^{\circ} \mathrm{C}$ and does not grow on $\mathrm{NaCl}$. Susceptible to cycloserine, gentamicin, amikacin, prothionamide and clarithromycin, but resistant to isoniazid ( $1 \mathrm{mg}$ $\left.\mathrm{l}^{-1}\right)$, rifampin $\left(32 \mathrm{mg} \mathrm{l}^{-1}\right)$, streptomycin $\left(8 \mathrm{mg} \mathrm{l}^{-1}\right)$, ethambutol $\left(2 \mathrm{mg} \mathrm{l}^{-1}\right)$ and ciprofloxacin $\left(4 \mathrm{mg} \mathrm{l}^{-1}\right)$. Positive reactions for heat-stable catalase $\left(68^{\circ} \mathrm{C}\right)$ and urease. Urease activity is weak. Negative reactions for niacin, nitrate reductase, arylsulfatase $(10 \mathrm{~d})$, acid phosphatase, hydrolysis of Tween 80 , acetamidase, benzamidase, nicotinamidase, pyrazinamidase, succinamidase and allantoinamidase. Strain does not show $\alpha$-esterase, $\beta$-esterase or $\beta$-galactosidase activities. Cell wall contains arabinose and galactose as major sugars and meso-diaminopimelic acid is the only diamino acid. MK- $9\left(\mathbf{H}_{2}\right)$ is the predominant menaquinone and small amounts of MK-8( $\left.\mathrm{H}_{2}\right)$ and $\mathrm{MK}-10\left(\mathrm{H}_{2}\right)$ are also found. Analysis of the fatty acids from the whole cells reveals a pattern of straight-chain, saturated and unsaturated fatty acids along with significant amounts of tuberculostearic acid. The strain cannot be precisely identified on the basis of its fatty acid pattern by using the MIDI mycobacterial database, but resembles species of the MAIS complex. TLC of mycolic acid methanolysates indicates the presence of $\alpha$-mycolates and wax esters. Only $\alpha$-mycolates and alcohols are detected by two-dimensional TLC. Combined results from HPLC and conventional biochemical testing are supportive of a novel species. Conclusive genetic evidence of a novel species has been demonstrated with $16 \mathrm{~S}$ rDNA analysis. The unique sequence has molecular signatures of slow-growing mycobacteria and Mycobacterium bohemicum seems to be phylogenetically near to the slow-growing Mycobacterium kansasii, Mycobacterium gastri, Mycobacterium szulgai and Mycobacterium avium-intracellulare complex. Type strain is DSM $44277^{\mathrm{T}}$ (deposited in the Deutsche Sammlung von Mikroorganismen und Zellkulturen, Braunschweig, Germany).

\section{ACKNOWLEDGEMENTS}

We would like to thank Professor Dr H. Wolf, Dr K.-H. Schröder and Dr J. Pawlowsky for helpful discussions and greatfully acknowledge the excellent assistance of E. Lang, G. Pausch, S. Vilsmeier, H. Oros, B. Haber, M. Pöhlmann, J. Köstler and H. Melzl during this study. 


\section{REFERENCES}

Böddinghaus, B., Rogall, T., Flohr, T., Blöcker, H. \& Böttger, E. C. (1990). Detection and identification of mycobacteria by amplification of rRNA. J Clin Microbiol 28, 1751-1759.

Corpe, R. F., Runyon, E. H. \& Lester, W. (1963). Status of disease due to unclassified mycobacteria. A statement of the subcommittee of therapy. Am Rev Respir Dis 87, 459-461.

Deutsche Sammlung von Mikroorganismen und Zellkulturen (1993). Caralogue of Strains. Braunschweig: Deutsche Sammlung von Mikroorganismen und Zellkulturen.

Deutsches Institut für Normung (1991). DIN 58943, parts 3,8 and 9. Berlin: Beuth.

Deutsches Zentralkomitee zur Bekämpfung der Tuberkulose (1991). Dic Bakteriologie der Tuberkulose. Pneumonologie 45, 753-774.

Goodfellow, M. \& Wayne, L. G. (1982). Taxonomy and Nomenclature. In The Biology of the Mycobacteria, pp. 472-521. Edited by C. Ratledge \& J. L. Stanford. London: Academic Press.

Haas, W. H., Kirschner, P., Ziesing, S., Bremer, H.-J. \& Böttger, E. C. (1993). Cervical lymphadenitis in a child caused by a previously unknown mycobacterium. $J$ Infect Dis 167, 237-240.

Kent, P. T. \& Kubica, G. P. (1985). Public health mycobacteriology: a guide for the level III laboratory. In US Department of Health and Human Services Publication, pp. 71-146. Atlanta, GA: Centers for Disease Control.

Kimura, M. (1980). A simple method for estimating evolutionary rates of base substitutions through comparative studies of nucleotide sequences. $J$ Mol Evol 16, 111-120.

Kirschner, P., Meier, A. \& Böttger, E. C. (1993). Genotypic identification and detection of mycobacteria - facing novel and uncultured pathogens. In Diagnostic Molecular Microbiology: Principles and Applications, pp. 173-190. Edited by D. H. Pershing, T. F. Smith, F. C. Tenover \& T. J. White. Washington, DC: American Society for Microbiology.

Kroppenstedt, R. M. (1985). Fatty acid and menaquinone analysis of actinomycetes and related organisms. Soc Appl Bacteriol Tech Ser 20, 173-199.

Kroppenstedt, R. M., Korn-Wendisch, F., Fowler, V. J. \& Stackebrandt, E. (1981). Biochemical and molecular genetic evidence for transfer of Actinoplanes armeniacus into the family Streptomycetaceae. Zentbl Bakteriol Parasitenkd Infektkrankh Hyg Abt 1 Oris Reihe C 2, 254-262.

Kubica, G. P. \& Wayne, L. G. (1984). The Mycobacteria - a Sourceboek, part A. New York: Marcel Dekker.

Kuykendall, L. D., Roy, M. A., O’Neill, J. J. \& Devine, T. E. (1988). Fatty acids, antibiotic resistance and deoxyribonucleic acid homology groups of Bradyrhizobium japonicum. Int $J$ Syst Bacteriol 38, 358-361.

Larsen, N., Olsen, G. J., Maidak, B. L., McCaughey, M. J., Overbeek, R., Macke, T., Marsh, T. L. \& Woese, C. (1993). The ribosomal database project. Nucleic Acids Res 21, 3021-3023.

Mesbah, M., Premachandran, U. \& Whitman, W. B. (1989). Precise measurement of the $\mathrm{G}+\mathrm{C}$ content of deoxyribonucleic acid by high-performance liquid chromatography. Int $J$ Syst Bacteriol 39, 159-167.

Miller, L. T. (1982). A single derivatization method for bacterial fatty acid methyl esters including hydroxy acids. $J$ Clin Microbiol 16, 584-586.

Minnikin, D. E., Hutchinson, I. G., Caldicott, A. B. \& Goodfellow, M. (1980). Thin-layer chromatography of methanolysates of mycolic acid-containing bacteria. $J$ Chromatogr 188, 221-233.

Minnikin, D. E., O’Donnell, A. G., Goodfellow, M., Alderson, G., Athalye, M., Schaal, A. \& Parlett, J. H. (1984). An integrated procedure for the extraction of isoprenoid quinones and polar lipids. J Microbiol Methods 2, 233-241.

Reischl, U., Pulz, M., Ehret, W. \& Wolf, H. (1994). PCR-based detection of mycobacteria in sputum samples using a simple and reliable DNA extraction protocol. Biotechniques 17, 844-846.

Rogall, T., Wolters, J., Flohr, T. \& Böttger, E. C. (1990). Towards a phylogeny and definition of species at the molecular level within the genus Mycobacterium. Int $J$ Syst Bacteriol 40, 323-330.

Runyon, E. H., Karlson, A. G., Kubica, G. P. \& Wayne, L. G. (1980). Mycobacterium. In Manual of Clinical Microbiology, pp. 150-179. Edited by E. H. Lennette, A. Balows, W. J. Hausler Jr \& J.P. Truant. Washington, DC: American Society for Microbiology.

Saitou, N. \& Nei, M. (1987). The neighbor-joining method: a new method for reconstructing phylogenetic trees. Mol Biol Evol 4, 406-425.

Sanger, R., Coulson, A. R., Hong, G. F., Hill, D. F. \& Petersen, G. B. (1982). Nucleotide sequence of bacteriophage lambda DNA. J Mol Biol 162, 729-773.

Schröder, K.-H., Naumann, L., Kroppenstedt, R. M. \& Reischl, U. (1997). Mycobacterium hassiacum sp. nov., a new rapidly growing thermophilic mycobacterium. Int J Syst Bacteriol 47, 86-91.

Shinnick, T. M. \& Good, R. C. (1994). Mycobacterial taxonomy. Eur J Clin Microbiol Infect Dis 13, 889-895.

Springer, B., Kirschner, P., Rost-Meyer, G., Schröder, K.-H., Kroppenstedt, R. M. \& Böttger, E. C. (1993). Mycobacterium interjectum, a new species isolated from a patient with chronic lymphadenitis. Int J Syst Bacteriol 31, 3083-3089.

Springer, B., Stockman, L., Teschner, K., Roberts, G. D. \& Böttger, E. C. (1996). Two-laboratory collaborative study on identification of mycobacteria : molecular versus phenotypic methods. $J$ Clin Microbiol 34, 296-303.

Stanek, J. L. \& Roberts, G. D. (1974). Simplified approach to identification of aerobic actinomycetes by thin-layer chromatography. Appl Microbiol 28, 226-231.

Tamaoka, J. \& Komagata, K. (1984). Determination of DNA base composition by reverse-phase high-performance liquid chromatography. FEMS Microbiol Lett 25, 125-128.

Visuvanathan, S., Moss, M. T., Stanford, J. L., Hermon-Taylor, J. \& McFadden, J. J. (1989). Simple enzymatic method for isolation of DNA from diverse bacteria. $J$ Microbiol Methods 10, 59-64.

Wolinsky, E. (1979). Nontuberculous mycobacteria and associated diseases. Am Rev Respir Dis 119, 107-159. 
